\title{
Perbandingan Algoritma K-Means dan K-Medoids untuk Pengelompokan Data Transaksi Bongkar Muat di Provinsi Riau
}

\author{
${ }^{1}$ Insanul Kamila, ${ }^{2}$ Ulya Khairunnisa, ${ }^{3}$ Mustakim \\ 1,2,3 Program Studi Sistem Informasi, Fakultas Sains dan Teknologi UIN Sultan Syarif Kasim Riau \\ ${ }^{1,2,3}$ Puzzle Research Data Technology, Fakultas Sains dan Teknologi UIN Sultan Syarif Kasim Riau \\ Jl. HR Soebrantas KM.18 No. 155 Panam Pekanbaru - Riau 28293 \\ Email: ${ }^{1} 11653201531 @$ student.uin-suska.ac.id, \\ 211653201346@student.uin-suska.ac.id, 33 mustakim@uin-suska.ac.id
}

\begin{abstract}
ABSTRAK
Data mining merupakan pemprosesan sebuah informasi dari suatu database yang dapat digunakan untuk berbagai kebutuhan sektor swasta. Salah satu metode dalam data mining, yaitu Clustering yang bertujuan untuk menemukan pengelompokan dari serangkaian pola, titik, objek maupun dokumen. Algoritma K-Means clustering merupakan algoritma yang berperan penting dalam bidang data mining serta sederhana untuk diimplementasikan dan dijalankan. Selain itu, terdapat pengembangan varian dari metode K-Means Clustering yaitu K-Medoids yang muncul sebagai penanggulangan kelemahan Algoritma K-Means yang sensitif terhadap outlier dikarenakan sebuah objek dengan sebuah nilai yang besar mungkin secara substansial menyimpang dari distribusi data. Penelitian ini membandingkan kedua algoritma pada suatu dataset. Adapun data yang digunakan merupakan data transaksi bongkar muat selama tahun 2017 pada PT Pelabuhan Indonesia I Cabang Dumai berdasarkan atribut agen, keterangan barang, jenis, dan jumlah ton. Dari percobaan yang dilakukan, diperoleh hasil pengolahan $K$ Means hanya membutuhkan waktu rata-rata 1 detik sedangkan pengolahan data pada $K$-Medoids membutuhkan waktu rata-rata 1 menit 38 detik pada RapidMiner. Nilai DBI pada $K$-Means lebih rendah dibandingkan $K$ Medoids yaitu masing-masing 0.112 dan 0.119. Perolehan cluster dominan, menunjukkan bahwa agen Buana Listya Tama TBK, PT mendominasi diikuti agen Samudera Sarana Karunia, PT.
\end{abstract}

Kata kunci: Bongkar Muat Barang, Clustering, Data Mining, Davies-Bouldin Index, K-Means, K-Medoids.

\section{A. PENDAHULUAN}

Data mining merupakan pemprosesan sebuah informasi dari suatu database yang dapat dilakukan meski tidak terlihat secara langsung. Data mining dapat digunakan untuk berbagai kebutuhan sektor swasta. Bidang industri misalnya pada perbankan, asuransi, dan obat-obatan dimana biasanya menggunakan teknik data mining untuk mengurangi biaya, meningkatkan pengetahuan, dan meningkatkan penjualan. Teknik analisis data pada umumnya berkisar seperti analisis regresi, analisis cluster, taksonomi numerik, analisis multidimensi, metode statistik multivariat, model stokastik, analisis deret waktu, teknik estimasi nonlinear, dan lainnya [1]. Kuantitas data yang diperoleh akan semakin bertumbuh lebih banyak lagi, dimana dibutuhkan alat dan teknik yang tepat dalam memproses data tersebut sehingga ekstraksi informasi yang dilakukan menjadi berguna untuk mengambil keputusan pada suatu perusahaan maupun organisasi kedepannya. Maka, dengan adanya data mining, mulai berkembang pesat menjadi bidang penelitian penting serta dibutuhkan untuk meningkatkan kajian ilmiah di bidang kecerdasan buatan dan statistik [1][2].

Salah satu metode pada data mining, yaitu Clustering yang merupakan metode pengelompokan data. Tujuan dari pengelompokan cluster ini adalah untuk menemukan pengelompokan dari serangkaian pola, titik, objek maupun dokumen. Objek yang berada didalam pengelompokkan cluster yang sama memiliki kemiripan antar satu kelompok dan memiliki perbedaan dengan objek oleh kelompok cluster lain [4]. Algoritma K-Means clustering merupakan algoritma yang berperan penting dalam bidang data mining serta sederhana untuk diimplementasikan dan dijalankan. Dalam prakteknya, algoritma ini umum digunakan karena relatif cepat dan mudah beradaptasi [13]. Selain itu, terdapat pengembangan varian dari metode $K$ Means Clustering yaitu K-Medoids. Bertujuan mengurangi sensitivitas dari partisi yang dihasilkan sehubungan dengan nilai-nilai ekstrim yang terdapat dalam dataset, penggunan medoids tidak berdasarkan dari pengamatan mean yang dimiliki oleh setiap cluster. Algoritma K-Medoids muncul sebagai penanggulangan kelemahan Algoritma $K$ Means yang sensitif terhadap outlier dikarenakan sebuah objek dengan sebuah nilai yang besar mungkin secara substansial menyimpang dari distribusi data [14].

Berdasarkan pada penelitian sebelumnya oleh Arbin, dkk (2015) terkait penggunaan metode $K$ Medoids dan K-Means sebagai perbandingan pengelompokan data statistik, disimpulkan bahwa analisis dari kedua pendekatan metode menghasilkan hasil yang baik dengan mean square error kurang dari 3\%. Berdasarkan dataset, $K$ Medoids menjadi pendekatan atau metode terbaik untuk mengelompokkan data. Untuk analisis lebih 
lanjut, dataset yang berbeda dari berbagai kategori data harus dilakukan pengujian. Jenis dataset yang berbeda dapat menghasilkan hasil pilihan pendekatan atau metode yang berbeda [3].

Kemudian pada penelitian oleh Aryuni, dkk (2018) mengenai Klasterisasi data Internet Banking di Bank XYZ menggunakan metode K-Means dan $K$-Medoids Clustering untuk melakukan segmentasi customer, diperoleh nilai k yang paling optimal pada kedua algoritma adalah 3 dengan nilai average within centroid distance $(\mathrm{W})$ sebesar 35.241 untuk K-Means dan sebesar 88.849 untuk K-Medoids. Selanjutnya total waktu eksekusi dari proses elbow method berturut-turut untuk K-Means dan $K$ Medoids adalah 3 detik dan 13 menit 44 detik. Maka dapat disimpulkan dalam pengolahan data, algoritma $K$-Means memiliki performa yang lebih baik daripada $K$-Medoids baik dari sisi nilai average within centroid distance dan kompleksitas waktu [15].

Agar tidak terjadi perbedaan pendapat lebih luas, penelitian ini akan langsung membandingkan kedua algoritma pada dataset bertujuan untuk menganalisa pola pengelompokkan dan menentukan algoritma yang baik dalam pengolahan data. Adapun data yang digunakan merupakan data transaksi bongkar muat oleh agen didermaga B selama tahun 2017 pada PT Pelabuhan Indonesia I Cabang Dumai. Dermaga B pada perusahaan tersebut merupakan transaksi muatan curah cair dan menghasilkan data terbanyak dibandingkan dermaga lainnya serta berpotensi menjadikan perusahaan PT Pelabuhan Indonesia I Cabang Dumai First Class Port dengan catatan ekspor minyak terbesar se-Sumatera[16]. Tanpa adanya agen yang melakukan transaksi dan mengandalkan fasilitas pelabuhan tersebut, tentu akan mempengaruhi objek pendapatan perusahaan. Untuk itu, berdasarkan pada atribut yang didapatkan yaitu agen, keterangan barang, jenis, dan jumlah ton akan dilakukan perbandingan algoritma K-Means dan K-Medoids. Percobaan yang dilakukan menggunakan aplikasi RapidMiner dengan nilai Davies-Bouldin Index sebagai acuan pengelompokkan cluster. Pola pengelompokan cluster yang didapatkan kemudian dianalisa dan menjadi sebuah informasi baru bagi perusahaan sebagai penentu tindakan lanjut sesuai analisa. Selain itu, diperoleh hasil algoritma terbaik dari uji validitas yang dilakukan pada $K$-Means dan $K$ Medoids.

\section{B. METODOLOGI PENELITIAN}

Berdasarkan pendahuluan yang telah dijabarkan, penelitian ini melalui beberapa tahap, berikut tahapan kerangka kerja dalam penyusunan penelitian:

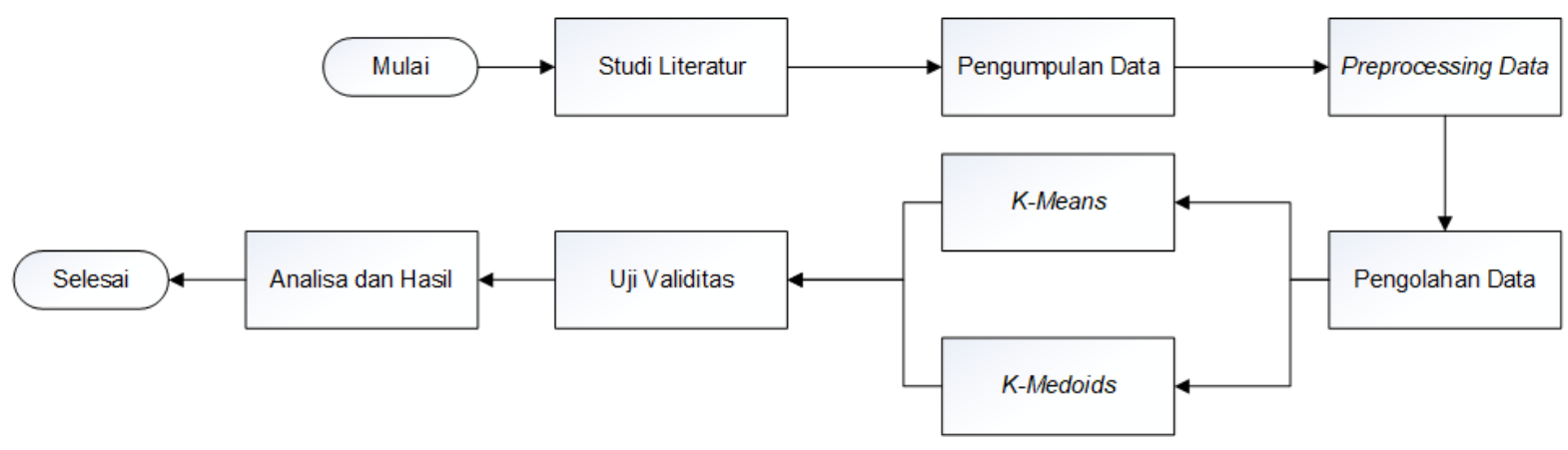

Gambar 1. Metodologi Penelitian

\section{TINJAUAN PUSTAKA \\ C.1. Data Mining}

Data mining merupakan proses mencari pola atau informasi menarik dalam data terpilih atau disebut juga suatu istilah yang digunakan untuk menguraikan penemuan pengetahuan di dalam database dengan menggunakan metode atau teknik tertentu. Data mining adalah proses menggunakan teknik statistik, matematika, kecerdasan buatan, dan machine learning dalam mengidentifikasi dan mengekstraksikan informasi yang bermanfaat bagi pengetahuan yang terkait dengan berbagai basis data berkapasitas besar [5]. Salah satu metode yang terdapat pada data mining yaitu Clustering yang berperan penting dalam mengeksplorasi data, menciptakan prediksi dan mengatasi anomali data. Pengelompokkan dalam suatu cluster, dikelompokkan menggunakan teknik reiteratif/ perulangan dengan karakteristik identik suatu dataset [6].

\section{C.2. Clustering}

Clustering atau pengelompokan data merupakan kegiatan mempertimbangkan sebuah pendekatan penting untuk mencari kesamaan dalam data dan menempatkan data yang sama ke dalam kelompok-kelompok. Clustering dianggap sebagai unsupervised learning yang paling penting dimana setiap masalah pada jenis ini berkaitan untuk menemukan struktur dalam kumpulan data yang tidak berlabel. Sebuah pengelompokkan cluster membagi kumpulan data kedalam sejumlah kelompok dimana kesamaan pada sebuah kelompok 
tertentu lebih besar daripada kelompok lainnya [7][18].

Penggunaan algoritma clustering tergantung pada jenis data yang ada pada tujuan dan aplikasi tertentu. Jika analisis cluster digunakan sebagai alat deskriptif atau eksplorasi, maka dimungkinkan untuk mencoba beberapa algoritma pada data yang sama untuk memperoleh apa yang diungkap oleh data tersebut. Secara umum, metode clustering dapat diklasifikasikan ke dalam beberapa kategori, salah satunya kategori partitioning method. Metode partisi ini didasarkan pada penentuan awal jumlah kelompok, kemudian realokasi objek secara iteratif untuk menemukan kembali kelompok-kelompok yang berada dalam satu titik. Salah satu algoritma yang populer dalam pengaplikasian metode partisi ini yaitu algoritma $K$-Means dan algoritma $K$ Medoids [18].

\section{C.3. K-Means}

K-Means clustering ialah metode analisis cluster yang bertujuan untuk memecah objek menjadi k cluster kemudian diamati di mana setiap objek cluster diperoleh melalui rata-rata terdekat. Algoritma ini merupakan salah satu pembelajaran yang terkenal sederhana dan mudah dipelajari sebagai pemecahan masalah pengelompokan dari sebuah dataset. Algoritma K-Means adalah algoritma evolusi yang mana metode operasinya memiliki artian yang serupa dengan nama algoritmanya. Algoritma ini mengelompokkan pengamatan ke dalam kelompok $\mathrm{k}$, di mana $\mathrm{k}$ merupakan parameter input. Tiap data kemudian ditetapkan pada setiap pengamatan cluster berdasarkan kedekatan pengamatan nilai rata-rata cluster. Nilai rata-rata pada cluster kemudian dihitung secara berulang pada proses awal. Adapun tahap-tahap melakukan $K$-Means Clustering sebagai berikut [8]:

1. Pilih nilai k sebagai pusat cluster awal secara acak.

2. Setiap data dalam dataset dibagi kedalam beberapa kelompok k cluster antara setiap titik dan pusat cluster yang didapatkan berdasarkan pada jarak Euclidean.

Adapun rumus perhitungan Euclidean Distance ditunjukkan pada persamaan (3.1) berikut [9]:

dengan :

$$
\mathrm{d}(\mathrm{x}, \mathrm{y})=\|\mathrm{x}-\mathrm{y}\|^{2}=
$$

$\mathrm{d}=$ jarak data ke pusat cluster

$\mathrm{x}=$ data ke pada atribut ke

$\mathrm{y}=$ titik pusat ke, pada atribut

3. Setiap pusat cluster dihitung ulang berdasarkan dari nilai rata-rata dalam cluster yang didapatkan.

4. Langkah 2 dan 3 ulangi sampai kelompok tersebut sesuai. Perulangan dapat didefinisikan secara berbeda tergantung pada implementasi, tetapi biasanya pada proses langkah 2 dan 3 dapat diulangi apabila kelompok cluster masih mengalami perubahan dan proses akan terhenti apabila tidak ada perubahan antar material dalam cluster.

\section{C.4. K-Medoids}

Algoritma PAM (Partioning Around Medoids) atau biasa juga disebut dengan algoritma $K$ Medoids, merupakan algoritma yang diwakili oleh cluster yaitu medoid. Perbedaan antara algoritma $K$ Medoids dengan algoritma $K$-Means yaitu algoritma $K$-Medoids menggunakan objek sebagai perwakilan (medoid) pusat cluster untuk tiap cluster, sementara algoritma $K$-Means membutuhkan nilai rata-rata (mean) sebagai pusat cluster [17][10].

Langkah-langkah penyelesaian $K$-Medoids adalah sebagai berikut[11]:

1. Inisialisasikan pusat cluster sebanyak jumlah cluster (k).

2. Setiap data atau objek dialokasikan ke cluster terdekat menggunakan persamaan ukuran jarak Euclidian Distance dengan rumus persamaan (3.1).

3. Pilih objek pada masing-masing cluster secara acak sebagai kandidat medoid baru.

4. Hitung jarak setiap objek yang terdapat pada masing-masing cluster dengan calon medoid baru.

5. Hitung total simpangan (S) dengan menghitung nilai total jarak baru - total jarak lama. Jika didapatkan $\mathrm{S}<0$, tukarlah objek dengan data cluster untuk membuat sekumpulan k objek baru sebagai medoid.

6. Ulangi langkah 3 sampai dengan 5 hingga tidak terjadi perubahan medoid, sehingga diperoleh cluster serta anggota cluster masing-masing.

\section{C.5. Davies-Bouldin Index (DBI)}

Davies-Bouldin Index (DBI) adalah metrik untuk mempertimbangkan/mengevaluasi hasil algoritma clustering yang diperkenalkan oleh David L. Davies dan Donald W. Bouldin bertepatan pada tahun 1979 [12]. Dengan menggunakan DBI suatu cluster akan dianggap memiliki skema clustering yang optimal adalah yang memiliki DBI minimal.

\section{HASIL DAN ANALISIS \\ D.1. Preprocessing Data}

Pengumpulan data dilakukan dengan melakukan wawancara dan observasi langsung di PT. Pelabuhan Indonesia I Cabang Dumai. Sumber data utama yaitu berasal dari data Dermaga B pada tahun 2017 sebanyak 3103 record data. Data tersebut akan diproses untuk mengasilkan pola ratarata transaksi bongkar muat curah cair oleh agen yang melakukan transaksi pada Dermaga B. Hal ini dapat memberikan informasi baru kepada 


\begin{tabular}{ccccc}
\hline 1 & A5 & 0,167 & 1,000 & 0,055 \\
2 & A15 & 0,167 & 1,000 & 0,052 \\
3 & A23 & 0,167 & 1,000 & 0,287 \\
4 & A2 & 0,167 & 0,000 & 0,194 \\
5 & A20 & 0,167 & 0,000 & 0,194 \\
$\ldots$ & $\ldots \ldots$ & $\ldots$. & $\ldots$. & $\ldots$. \\
362 & A20 & 0,833 & 1,000 & 0,555 \\
363 & A20 & 0,889 & 1,000 & 0,083 \\
$\ldots$. & $\ldots \ldots$ & $\ldots$. & $\ldots$. \\
3089 & A5 & 0,167 & 1,000 & 0,055 \\
\hline
\end{tabular}

\section{D.2. Proses Data}

Setelah melakukan tahapan preprocessing data, data kemudian diolah menggunakan RapidMiner untuk menunjukkan nilai DaviesBouldin Index (DBI) sebagai acuan pengelompokkan cluster terbaik. Pengujian dilakukan pada cluster $\mathrm{k}=2$ sampai dengan $\mathrm{k}=10$. Berikut hasil pengolahan data ditunjukkan pada gambar 2:

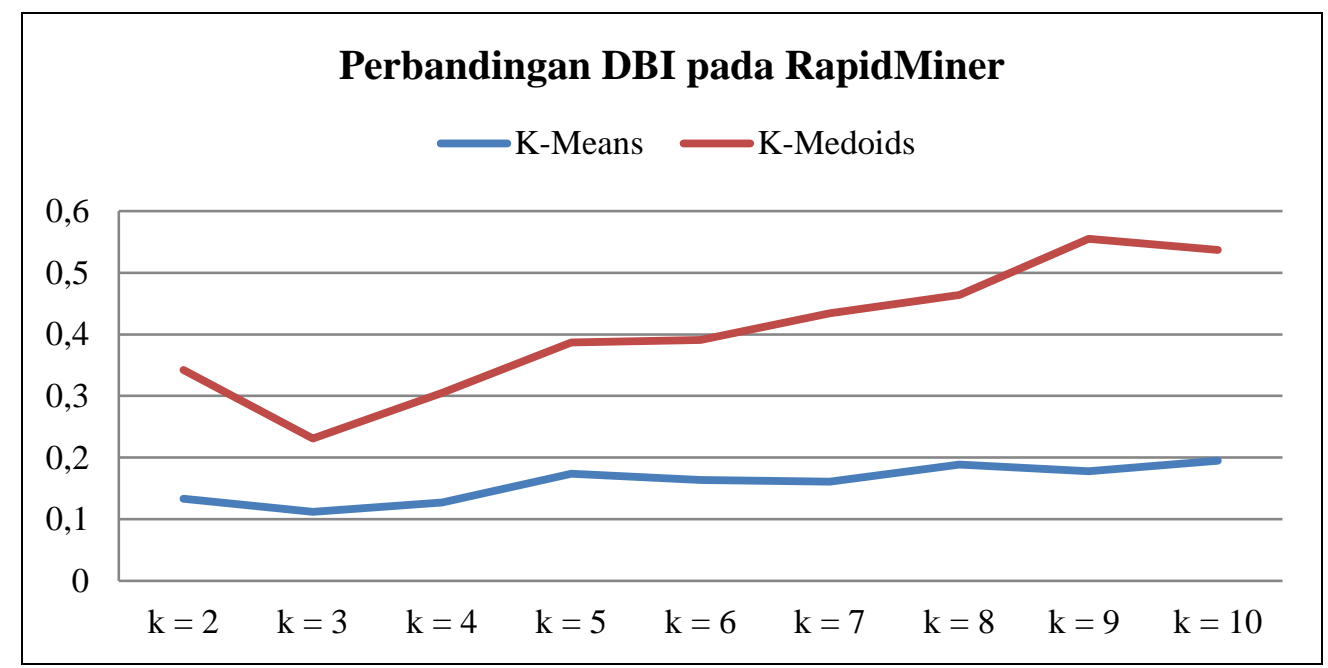

Gambar 2. Perbandingan DBI pada RapidMiner

Untuk melihat secara rinci pengujian tiap cluster pada masing-masing algoritma, ditunjukkan pada tabel 6:

Tabel 6. Hasil Perbandingan DBI

\begin{tabular}{ccc}
\hline Cluster & K-Means & K-Medoids \\
\hline $\mathrm{k}=2$ & 0.133 & 0.209 \\
$\mathrm{k}=3$ & 0.112 & 0.119 \\
$\mathrm{k}=4$ & 0.127 & 0.178 \\
$\mathrm{k}=5$ & 0.174 & 0.213 \\
$\mathrm{k}=6$ & 0.164 & 0.227 \\
$\mathrm{k}=7$ & 0.161 & 0.273 \\
\hline
\end{tabular}

\begin{tabular}{ccc}
\hline Cluster & K-Means & K-Medoids \\
\hline $\mathrm{k}=8$ & 0.189 & 0.275 \\
$\mathrm{k}=9$ & 0.178 & 0.377 \\
$\mathrm{k}=10$ & 0.195 & 0.342 \\
\hline
\end{tabular}

Berdasarkan perbandingan nilai Davies-Bouldin Index diatas, menunjukkan bahwa $\mathrm{k}=3$ menjadi cluster terbaik. Untuk melihat pembagian tiap items pada masing-masing pengelompokkan $\mathrm{k}=3$ dapat ditunjukkan pada gambar 3 . 


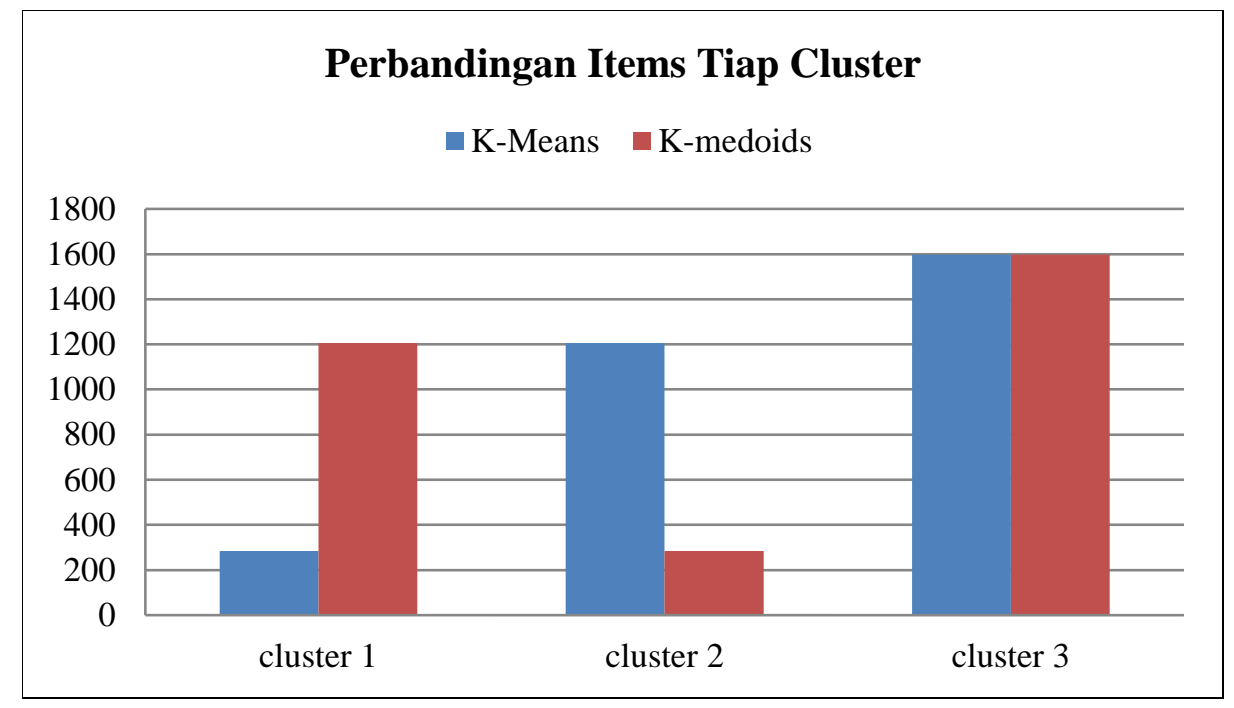

Gambar 3. Perbandingan Items Tiap Cluster

Diperoleh pola pengelompokkan tiap cluster hanya pada satu jenis atribut bongkar barang atau muat barang, dimana pada cluster dominan didapatkan atribut berjenis muat barang dengan transaksi CPO (Crude Palm Oil) yang paling dominan. Pada cluster 3 ini juga menunjukkan agen Buana Listya Tama TBK, PT mendominasi sebanyak 18,77\% dengan jumlah rata-rata transaksi 2847,22 ton. Selanjutnya oleh agen Samudera Sarana Karunia, PT sebanyak 17,02\% dengan jumlah rata-rata transaksi 2827,32 ton.

\section{E. KESIMPULAN}

Perbandingan antar kedua algoritma clustering, $\quad K$-Medoids dan $K$-Means tidak menunjukkan perbedaan yang signifikan mengenai pengelompokkan data. Adapun dalam pengolahannya, K-Means hanya membutuhkan waktu rata-rata 1 detik sedangkan pengolahan data pada $K$-Medoids membutuhkan waktu rata-rata 1 menit 38 detik yang artinya apabila makin tinggi iterasi dan pengelompokkan yang ditentukan, maka pengolahan data akan semakin lama. Selanjutnya pada nilai Davies-Bouldin Index diperoleh nilai $\mathrm{k}=3$ pada $K$-Means lebih rendah dibandingkan $K$ Medoids. Selain itu, pengolahan data berlanjut pada k=10 juga menunjukkan nilai DBI pada K-Means lebih rendah. Pola pengelompokkan masing-masing cluster diperoleh berdasarkan pembagian jenis barang sesuai jenis bongkar atau muat barang. Perolehan cluster dominan, menunjukkan bahwa agen Buana Listya Tama TBK, PT mendominasi diikuti dengan agen Samudera Sarana Karunia, PT. sebagai agen yang melakukan transaksi terbanyak.

\section{F. UCAPAN TERIMA KASIH}

Terima kasih yang sebesar-besarnya kepada Tim Puzzle Research Data Technology (PREDATECH) Fakultas Sains dan Teknologi Universitas Islam Negeri Sultan Syarif Kasim Riau atas segala masukan, dukungan moral dan materi, koreksi dan bantuan dalam kegiatan penelitian ini sehingga penelitian ini dapat terselesaikan dengan baik

\section{REFERENSI}

[1] Okfalisa, Mustakim, Gazalba I \& Reza NGI . Comparative Analysis Of K-Nearest Neighbor And Modified K-Nearest Neighbor Algorithm For Data Classification. Information Technology, Information Systems and Electrical Engineering (ICITISEE), 2017 2nd International conferences on IEEE. 2017 : 294298.

[2] Uddin H \& Nafis MT. Students Academic Performance Using Partitioning Clustering Algorithms. International Journal of Advanced Research in Computer Science. 2017 ; 8(5) : 640-644.

[3] Arbin N, Suhaimi, NS, Mokhtar, NZ \& Othman Z. Comparative Analysis between $K$ Means and K-Medoids for Statistical Clustering. 2015 3rd International Conference on Artificial Intelligence, Modelling and Simulation. IEEE. 2015: 117-121.

[4] Balabantaray RC, Sarma C \& Jha M. Document clustering using $K$-Means and $K$ Medoids. International Journal of Knowledge Based Computer System. 2013 ; 1(1) : 7-13.

[5] Han J, Kamber M, dan Jian P. Data Mining : Concepts and techniques. USA : Elsevier Inc. 2012.

[6] Arora P, Dr Deepali, Varshney S. Analysis of K-Means and K-Medoids Algorithm For Big Data. International Conference on Information Security \& Privacy (ICISP2015). Nagpur. 2016; 507-512. 
[7] RuiXu \& Donald, C.W. 2009. Clustering. John Wiley \& Sons, Inc.

[8] Singh K, Malik D \& Naveen Sharma. Evolving Limitations in K-Means Algorithm in Data Mining and Their Removal. IJCEM International Journal of Computational Engineering \& Management. 2011; 12: 105109.

[9] Ramadhan A, Efendi Z, \& Mustakim. Perbandingan K-Means dan Fuzzy C-Means untuk Pengelompokan Data User Knowledge Modeling. Seminar Nasional Teknologi Informasi Komunikasi dan Industri. 2017; 219226.

[10] Kaur, Noor K et al. "K-Medoids Clustering Algorithm”. Vol. 1, Issue 1. April 2014.

[11] Han J, Kamber M. Data Mining: Concept and Techniques. Waltham: Morgan Kauffman Publisher; 2006.

[12] Irhamni F, Damayanti F, Khusnul K B \& A Mifftachul. Optimalisasi Pengelompokan Kecamatan Berdasarkan Indikator Pendidikan Menggunakan Metode Clustering Dan Davies Bouldin Index. Seminar Nasional Sains dan Teknologi 2014. Jakarta. 2014 : 1-5.
[13] Wu, Xindong \& Kumar, Vipin. 2009. The Top Ten Algorithms in Data Mining. London: CRC Press.

[14] Triyanto WA. Algoritma K-Medoids Untuk Penentuan Strategi Pemasaran Produk. Jurnal Teknik Industri, Mesin, Elektro, dan Ilmu Komputer. 2015; 6(1):183-188

[15] Aryuni M, Madyatmadja ED, Miranda E. Penerapan K-Means Dan K-Medoids Clustering Pada Data Internet Banking Di Bank Xyz. Jurnal Teknik dan Ilmu Komputer. $2018 ; 7(27): 349-356$.

[16] Diakses oleh http://ekonomi.metrotvnews.com pada Minggu, 22 Oct 2017.

[17] IBRAHIM, L. Fattouh. Using Of Clustering And Ant-Colony Algorithms CWSP-PAM-ANT In Network Planning. In: Digital Telecommunications, $2006 . \quad$ ICDT'06. International Conference on. IEEE, 2006. p. 63-63.

[18] Madhulatha TS. Comparison Between $K$ Means and K-Medoids Clustering Algorithms. International Journal of Advanced Computing (IJAC). 2011; 3(2) : 65-69. 